\title{
DIAGNOSA COVID-19 CHEST X-RAY DENGAN CONVOLUTION NEURAL NETWORK ARSITEKTUR RESNET-152
}

\author{
Widi Hastomo ${ }^{1}$ dan Adhitio Satyo Bayangkari Karno ${ }^{2}$ \\ Fakultas Ekonomi Digital, ITB Ahmad Dahlan Jakartal, Fakultas Teknologi Informasi,Universitas \\ Gunadarma ${ }^{2}$
}

\section{ABSTRACT}

The availability of medical aids in adequate quantities is very much needed to assist the work of the medical staff in dealing with the very large number of Covid patients. Artificial Intelligence (AI) with the Deep Learning (DL) method, especially the Convolution Neural Network (CNN), is able to diagnose Chest X-ray images generated by the Computer Tomography Scanner (C.T. Scan) against certain diseases (Covid). Resnet Version-152 architecture was used in this study to train a dataset of 10.300 images, consisting of 4 classifications namely covid, normal, lung opacity with 3,000 images each and viral pneumonia 1,000 images. The results of the study with 50 epoch training obtained very good values for the accuracy of training and validation of $95.5 \%$ and $91.8 \%$, respectively. The test with 10.300 image dataset obtained $98 \%$ accuracy testing, with the precision of each class being Covid (99\%), Lung_Opacity (99\%), Normal (98\%) and Viral pneumonia $(98 \%)$.

\begin{tabular}{|c|c|}
\hline Article History & ABSTRAK \\
\hline Received 2021-07-16 & \multirow{6}{*}{$\begin{array}{l}\text { Ketersediaan alat bantu medis dalam jumlah memadai sangat diperlukan untuk } \\
\text { membantu kerja para medis dalam menangani jumlah pasien Covid-19 yang sanga } \\
\text { banyak. Artificial Intellience (AI) dengan metode Deep Learning (DL), khususnya } \\
\text { Convolution Neural Network (CNN), mampu mendiagnosa image Chest X-Ray yang } \\
\text { dihasilkan oleh alat Computer Tomography Scanner (CT Scan) terhadap penyaki } \\
\text { tertentu (Covid). Arsitektur Resnet-152 dipergunakan dalam penelitian ini untuk } \\
\text { melakukan trainning dataset } 10.300 \text { image, terdiri dari } 4 \text { klasifikasi yaitu covid } \\
\text { normal, lung opacity masing-masing dengan jumlah data } 3.000 \text { image dan vira } \\
\text { pneumonia } 1.300 \text { image. Hasil penelitian dengan trainning } 50 \text { epoch diperoleh nila } \\
\text { yang sangat baik untuk akurasi trainning dan validasi sebesar } 95,5 \% \text { dan } 91,8 \% \text {. Uj } \\
\text { testing dengan jumlah data uji } 19.300 \text { image diperoleh akurasi testing } 99 \% \text {, dengan } \\
\text { presisi tiap kelas adalah Covid ( }(99 \%) \text {, Lung Opacity }(99 \%) \text {, Normal }(98 \%) \text { dan Viral } \\
\text { Pneumonia ( } 98 \%) \text {. }\end{array}$} \\
\hline Revised 2021-07-23 & \\
\hline Accepted 2021-07-31 & \\
\hline & \\
\hline Key words & \\
\hline $\begin{array}{l}\text { Covid-19, Convolution Neral } \\
\text { Network, Chest } x \text {-ray }\end{array}$ & \\
\hline
\end{tabular}

\section{PENDAHULUAN}

Lebih dari satu tahun kita telah melalui pandemi Covid-19, jika merujuk informasi dari ourworldindata.org dalam tiga bulan terakhir ini, kasus kematian di Indonesia yang diakibatkan oleh Covid-19 mengalami kenaikan sebesar 101\% [1]. Melihat jumlah kenaikan yang signifikan kecil kemungkinan pandemi ini akan segera berakhir. Banyak peneliti telah berupaya dalam mengurangi pencegahan penularan Covid-19 [2]-[9], [10]. Untuk lebih efektif mengontrol penyebaran Covid-19 [11] dan mengobati pasien serta mengurangi angka kematian, citra medis dapat memiliki peran yang sangat penting [12]. Saat ini praktek uji klinis, radiografi chest $x$-ray (CXR) dan computed tomography (CT) adalah dua modalitas pencitraan untuk mendeteksi Covid-19, untuk menilai keparahannya, dan memantau prognosisnya (respon terhadap pengobatan) [13].

Meski CT bisa mencapai sensitivitas deteksi yang lebih tinggi, namun radiografi rontgen dada/CXR lebih banyak dan biasa digunakan dalam praktek klinis karena kelebihannya yaitu; termasuk dalam kategori biaya rendah, dosis radiasi rendah, mudah dioperasikan dan aksesibilitas lebih luas di rumah sakit umum [14]. Namun, pneumonia bisa menjadi penyebab dari berbagai jenis virus dan bakteri. Hal ini menjadi tantangan dan memerlukan waktu lebih banyak bagi ahli radiologi di komunitas rumah sakit untuk membaca gambar rontgen dada dalam jumlah besar serta untuk mendeteksi pneumonia yang terinfeksi Covid-19 dan membedakannya dari yang lain, pneumonia yang tidak terinfeksi Covid-19 yang didapat dari masyarakat. Karena ada banyak kesamaan antara 
pneumonia yang terinfeksi Covid-19 dan jenis virus atau bakteri lainnya. Kondisi seperti ini menjadi tantangan klinis yang dihadapi oleh ahli radiologi dalam masa pandemi ini [15].

Untuk mengatasi tantangan ini, pengembangan deteksi dengan bantuan komputasi berdasarkan pemrosesan citra medis dan pembelajaran mesin telah menarik minat penelitian ini, yang bertujuan untuk mendiagnosa karakteristik penyakit secara otomatis dan menyediakan alat pendukung pengambilan keputusan yang berharga bagi ahli radiologi untuk deteksi dan diagnosis yang lebih akurat atau efisien dari pneumonia yang terinfeksi Covid-19. Convolution Neural Network (CNN) dengan arsitektur ResNet-152 menjadi pilihan karena dapat manghasilkan akurasi yang baik [16], cukup memerlukan komputasi yang minimum serta dapat diaplikasikan oleh komputer sederhana, hal ini berarti setiap rumah sakit dan komunitas tidak perlu melakukan investasi yang besar dalam penerapannya.

\section{TINJAUAN PUSTAKA}

Prinsip kerja CNN dapat digambarkan dengan dua langkah. Pertama, jaringan dilatih melalui label yang diberikan dataset dan fitur multi-skala yang diekstraksi. Kedua, berdasarkan fitur yang diekstraksi pada langkah pertama, dilakukan klasifikasi [17]. CNN terdiri dari beberapa komponen penting, antara lain convolutional layer, fungsi aktivasi, pooling layer dan fully connected layer. CNN sederhana biasanya terdiri dari beberapa lapisan, sementara beberapa model CNN yang sangat dalam dapat mencakup ratusan lapisan. Misalnya, satu versi ResNet populer saat ini terdiri dari 152 lapisan [16].

Lapisan convolutional adalah komponen penting dari CNN, dan neuron di lapisan convolutional sensitif terhadap setiap bagian kecil dari input gambar. Dalam terminologi CNN, parameter pertama dari konvolusi biasanya disebut input, parameter kedua disebut fungsi kernel, dan output disebut peta fitur, ditunjukkan dalam persamaan (1), di mana x adalah input, $\omega$ adalah kernel fungsi, $s(t)$ menunjukkan peta fitur keluaran. Definisi operasi konvolusi dua dimensi (2D) ditunjukkan pada persamaan (2), di mana $I$ adalah input, $K$ menunjukkan kernel 2D fungsi [18].

$$
\begin{aligned}
& \quad s(t)=(x * \omega) *(t)=\sum x(a) \omega(t \\
& -a) \\
& S(i, j)=(I * K)(i, j)=\sum_{m n} \sum_{a=-\infty} I(\boldsymbol{m}, n) K\left(i-\boldsymbol{m}_{1} j-n\right)
\end{aligned}
$$

Pemilihan fungsi aktivasi untuk CNN sangat penting. Saat ini, Rectified Linear Unit (ReLU) adalah fungsi aktivasi pilihan [19], yang didefinisikan sebagai berikut:

$$
f(x)=\max (0, x) \quad(3)
$$

Lapisan penyatuan dapat mengurangi biaya komputasi dengan menghitung karakteristik statistik keseluruhan dari wilayah persegi panjang yang berdekatan dari suatu lokasi untuk menggantikan output dari lapisan konvolusi pada daerah tersebut [2]. Misalnya, lapisan penyatuan maksimal, jenis layer penyatuan yang paling umum digunakan, menghitung nilai maksimum daerah persegi panjang yang berdekatan. Kecuali max-pooling, ada banyak pooling layer lainnya, seperti average-pooling dan L2-norm pooling [20].

Lapisan terakhir CNN adalah lapisan yang terhubung penuh, dimana setiap neuron dalam lapisan terhubung ke setiap neuron di lapisan berikutnya [18]. Output dari lapisan sebelumnya bisa dikirim ke lapisan yang terhubung penuh sebagai input, dan probabilitas skor untuk setiap kelas di mana gambar input dapat dihitung. Kelas dengan nilai tertinggi adalah hasil klasifikasi akhir dari citra masukan. Singkatnya, lapisan yang sepenuhnya terhubung menggabungkan fitur gambar yang paling menonjol untuk menyimpulkan kategori gambar [21].

ResNet-152 memperkenalkan konsep pembelajaran residual di mana pengurangan fitur dipelajari dari layer input dengan menggunakan koneksi pintasan (secara langsung menghubungkan input dari (n) layer ke beberapa $(\mathrm{n}+\mathrm{x})$ layer, yang ditampilkan pada panah melengkung). Telah terbukti bahwa pembelajaran residual dapat meningkatkan kinerja pelatihan model, terutama ketika model memiliki jaringan yang dalam dengan lebih dari 20 layer, serta juga berkisar pada masalah 
penurunan akurasi dalam jaringan yang dalam [16]. Arsitektur jaringan Resnet-152 terlihat pada gambar 1, jaringan Resnet-152 mencapai hasil pelatihan yang lebih baik, hal tersebut linier dengan validasi error yang lebih rendah dari arsitektur lainnya, seperti terlihat pada gambar 2.

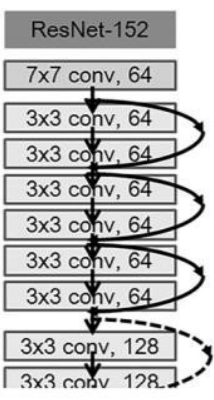

152 layers

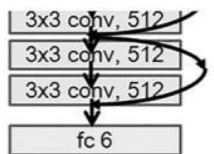

Gambar 1. Arsitektur Resnet-152 [22].

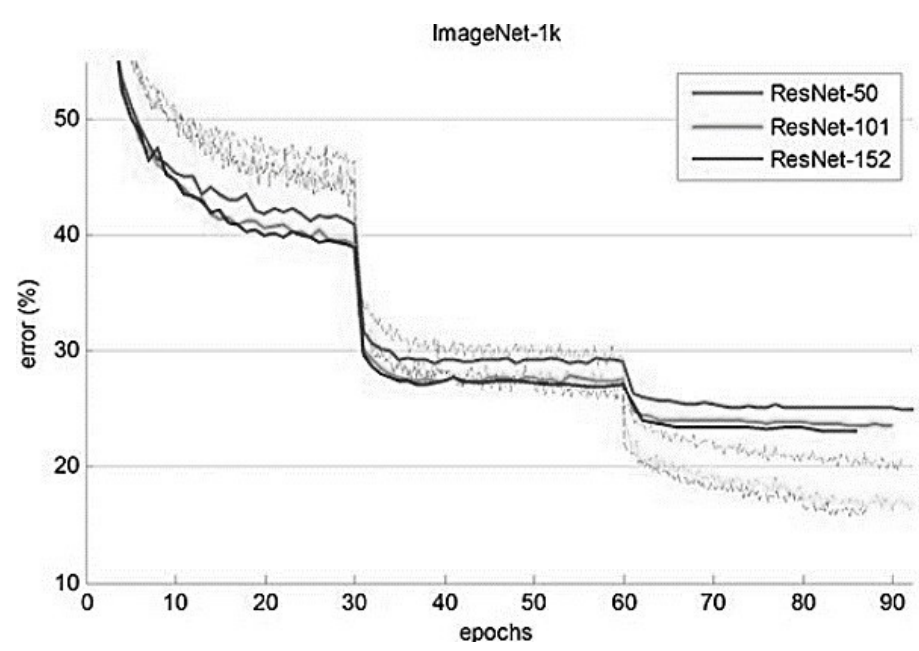

Gambar 2. Validasi error 3 arsitektur CNN [16].

\section{METODE}

Dataset yang digunakan dalam penelitian ini bersumber dari kaggle.com [23], jumlah dataset yaitu 10.300 image chest $\mathrm{x}$-ray. Secara klinis setiap image chest $\mathrm{x}$-ray di klasifikasikan ke dalam empat kelas kelas [24] dengan jumlah dataset tiap kelas terlihat dalam Gambar 3:
0 - Normal
$3.000(29.1 \%)$
1 - Viral Pneumonia
$1.300(12 \%)$
2 - Lung_Opacity
$3.000(29.1 \%)$
3 - Covid
$3.000(29.1 \%)$
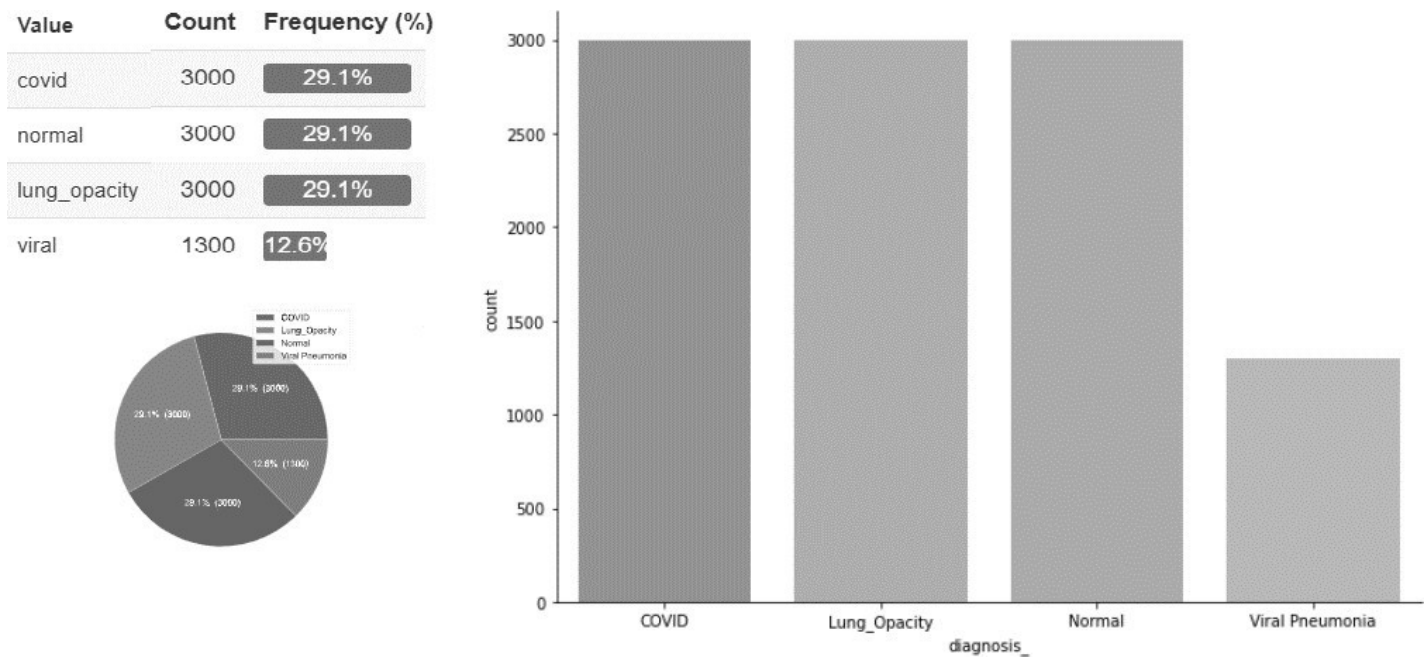

Gambar 3. Pie dan histogram dataset 

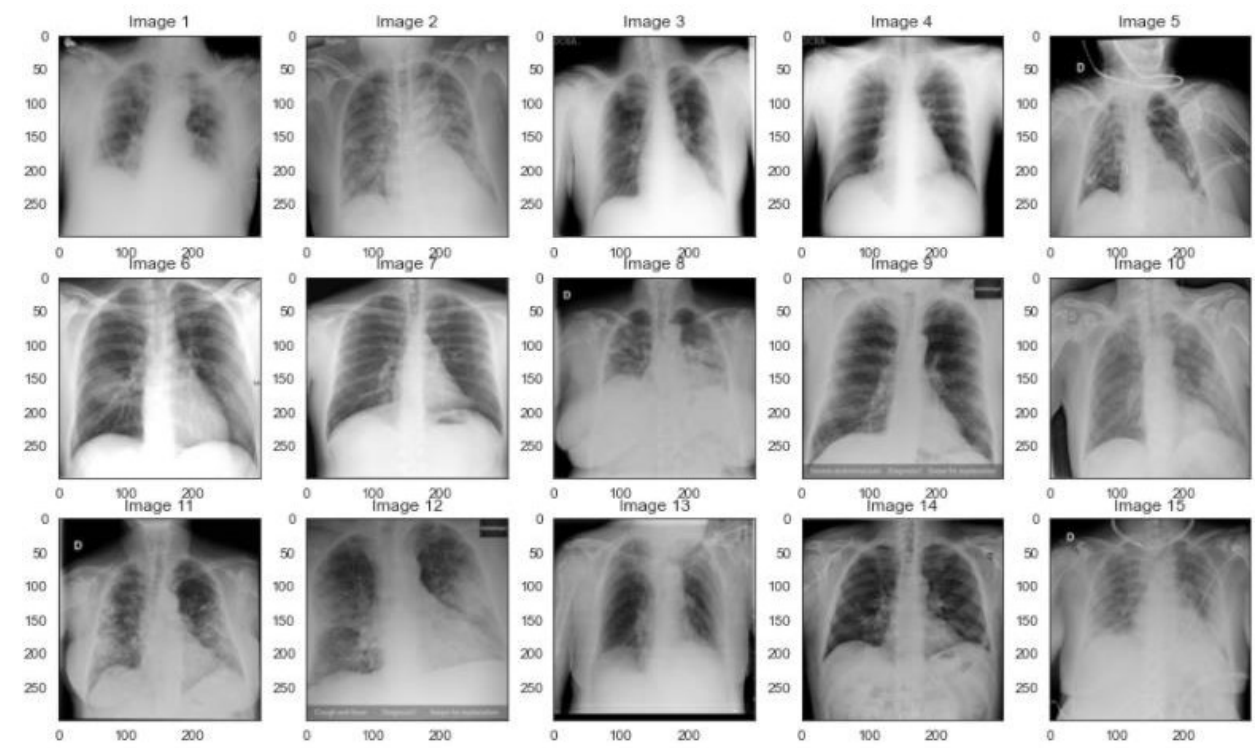

Gambar 4. Dataset Image Chest X-Ray

Pembagian dataset menjadi 4 kategori yaitu Normal, Viral Pneumonia, Lung Opacity dan Covid. Pada gambar 4 yaitu dataset image chest $x$-ray. Data tersebut terdiri dari empat kelas, yakni; (a) 3000 images Covid-19, (b) 3000 images normal, (c) 3000 images lung opacity, (d) 1300 images viral pneumonia. Dari jumlah data images sejumlah $20 \%$ digunakan untuk data testing, sisanya untuk data training. Detail skema penelitian yang diusulkan seperti terlihat dalam Gambar 5.

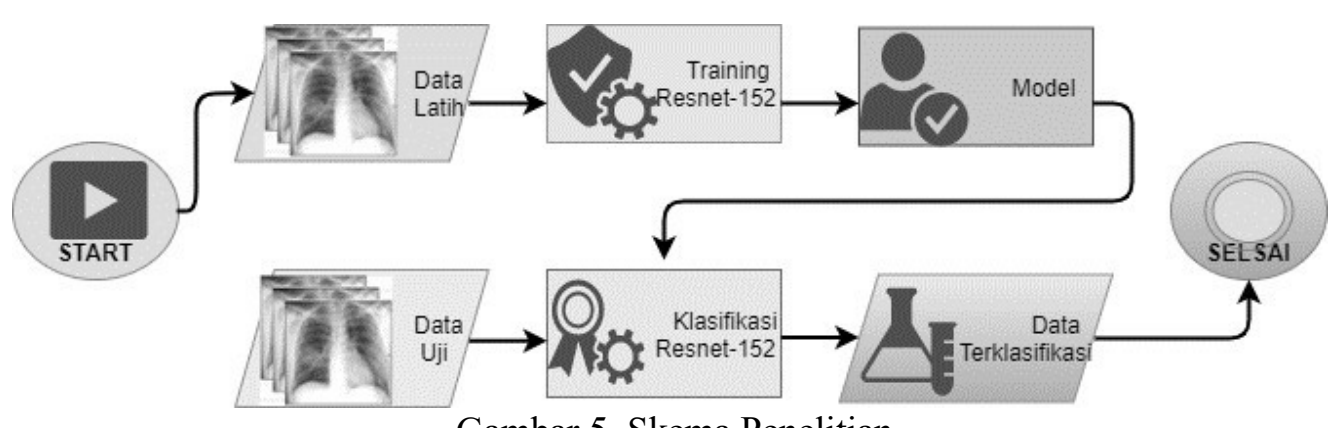

Gambar 5. Skema Penelitian

Semua gambar sampel memiliki berbagai ukuran. Oleh karena itu, gambar-gambar itu ada yang diubah ukurannya menjadi $224 \times 224$ piksel. Normalisasi data dilakukan untuk pembelajaran sistem yang lebih baik serta untuk mencegah overfitting dan memudahkan generalisasi. Dataset dipartisi menjadi tiga set berbeda: set pelatihan, set validasi, dan set pengujian. Dengan set pelatihan dan validasi, model CNN yang diusulkan dilatih. Eksperimen dijalankan hingga epoch yang berbeda seperti 50, 60, dan 100. Setelah menjalankan jaringan selama 50 epoch, akurasi jaringan mulai jenuh. Dengan 50 epoch, model mencapai akurasi pelatihan dan validasi yang diharapkan.

Fully connected layer (FCL) dari model dipilih untuk mengekstrak fitur. Fitur vektor diekstraksi dari setiap gambar pelatihan dengan lapisan ini. Fitur vektor dari semua gambar ini dimasukkan ke dalam empat pengklasifikasi arstitektur ResNet-152. Untuk menyesuaikan hyperparameter pengklasifikasi yang terbaik. Terakhir, semua pengklasifikasi ResNet-152 digabungkan untuk mengembangkan ansambel pengklasifikasi, yang memprediksi label kelas berdasarkan suara mayoritas pengklasifikasi ResNet-152. Kinerja sistem yang diusulkan dievaluasi dalam hal confusion matrix, presisi, akurasi, dan skor F1. Dengan demikian, dataset siap untuk dimasukkan ke dalam jaringan CNN dan untuk melatih model. 


\section{HASIL DAN PEMBAHASAN}

Hasil eksperimen dengan jumlah data 10.300 image dan melakukan 50 epoch dengan memperoleh nilai akurasi trainning dan validasi sangat baik yaitu masing $99,9 \%$ dan $93 \%$. (Gambar 6). Terlihat grafik akurasi dan grafik loss sudah tidak mengalami banyak perubahan setelah trainning 50 epoch (Gambar 7 dan 8).

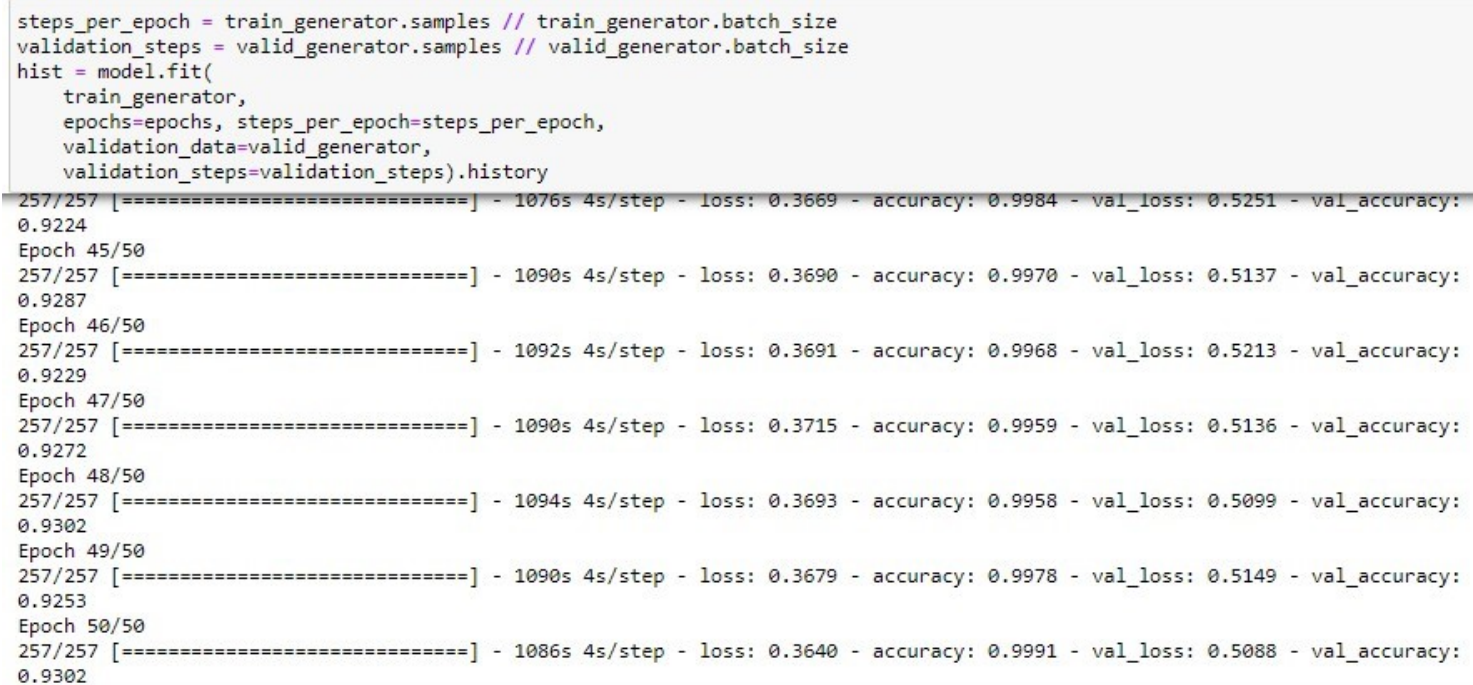

Gambar 6. Akurasi trainning 99,9\% dan validasi $93 \%$
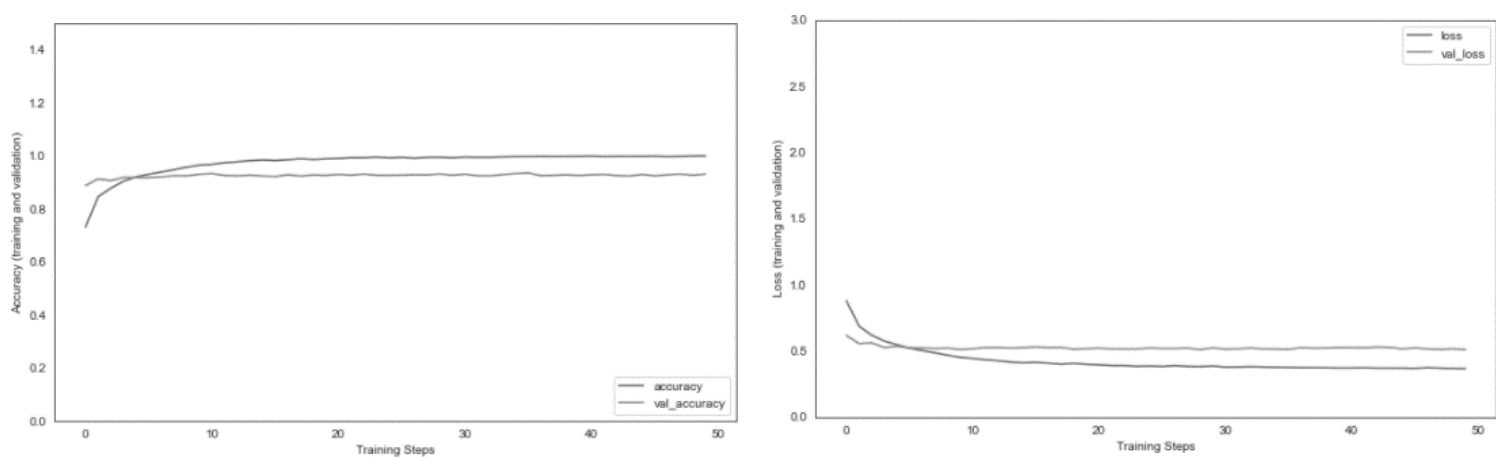

Gambar 7. Grafik akurasi trainning dan testing Gambar 8. Grafik Loss Value trainning dan testing

Dari hasil training yang telah dilakukan diperoleh model matrik kernel. Model ini dapat dipergunakan untuk menguji image data yang belum diketahui labelnya. Agar lebih menyakinkan maka dilakukan pengujian kembali dengan menggunakan 10.300 dataset data image chest $x$-ray, terdiri dari 4 kelas masing-masing berjumlah 1000 image. Hasil pengujian ini diperoleh nilai presisi untuk tiap kelas sebagai berikut:

a. COVID adalah 2.971 dari 3.007, presisinya sebesar $99 \%$.

b. Lung Opacity 2.953 dari 2.989 , presisinya sebesar $99 \%$.

c. Normal adalah 2.941 dari 2.986 , presisinya sebesar $98 \%$.

d. Pneumonia, 1.292 dari 1.318, presisinya sebesar $98 \%$. berikut :

Detail perhitungan untuk mengukur presisi lainnya ditunjukan dalam bentuk tabel 1 , sebagai

Tabel 1. Report Klasifikasi

\begin{tabular}{|c|c|}
\hline COVID & A \\
\hline Lung Opacity & B \\
\hline Normal & $\underline{\mathrm{C}}$ \\
\hline Viral Pneumonia & D \\
\hline
\end{tabular}




\begin{tabular}{|c|c|c|c|c|c|c|}
\hline & & $\mathbf{A}$ & B & $\mathbf{C}$ & D & Support \\
\hline \multirow{5}{*}{ 己. } & $\mathbf{A}$ & 2971 & 16 & 10 & 3 & 3.000 \\
\hline & B & 19 & 2953 & 28 & 0 & 3.000 \\
\hline & $\mathbf{C}$ & 16 & 20 & 2941 & 23 & 3.000 \\
\hline & D & 1 & 0 & 7 & 1292 & 1.300 \\
\hline & & 3,007 & 2,989 & 2,986 & 1,318 & 10.300 \\
\hline
\end{tabular}

\begin{tabular}{cccc}
\hline & Precision & Recall & f1-score \\
\hline A & $2.971 / 3,007=0.99$ & $2.971 / 3.000=0.99$ & $2 * 2.971 /(993+3000)=0.99$ \\
\hline B & $2.953 / 2,989=0.99$ & $2.953 / 3.000=0.98$ & $2 * 2.953 /(2,989+3000)=0.99$ \\
\hline C & $2.941 / 2,986=0.98$ & $2.941 / 1.300=0.98$ & $2 * 2.941 /(2,986+1.300)=0.98$ \\
\hline D & $2.292 / 1,318=0.98$ & $2.292 / 3.000=0.99$ & $2 * 2.292 /(1,318+3000)=0.99$ \\
\hline
\end{tabular}

Hasil akurasi Resnet- $152=(2.971+2.953+2.941+2.292) / 4000=\mathbf{0 . 9 9}$

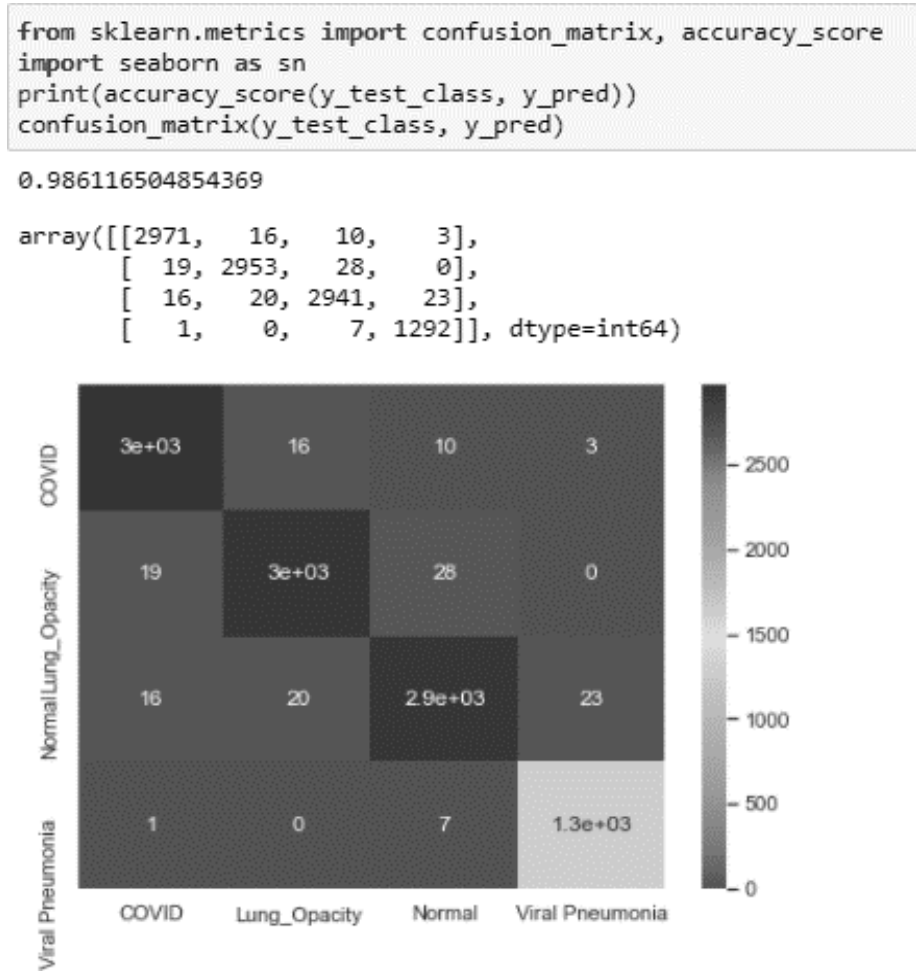

Gambar 9. Confusion Matrik

Modul sklearn phyton dapat dipergunakan untuk mengukur akurasi dan memvisualisasikan matrik cofusion seperti yang ditampilkan dalam Gambar 9 dan 10.

\begin{tabular}{|c|c|c|c|c|}
\hline \multicolumn{5}{|c|}{$\begin{array}{l}\text { \#CLASSIFICATION REPORT } \\
\text { from sklearn.metrics import classification_report } \\
\text { print(classification_report(y_test_n, y_prediction_n, target_names=class_names)) }\end{array}$} \\
\hline & precision & recall & f1-score & support \\
\hline COVID & 0.99 & 0.99 & 0.99 & 3000 \\
\hline Lung_Opacity & 0.99 & 0.98 & 0.99 & 3000 \\
\hline Normal & 0.98 & 0.98 & 0.98 & 3000 \\
\hline Viral Pneumonia & 0.98 & 0.99 & 0.99 & 1300 \\
\hline accuracy & & & 0.99 & 10300 \\
\hline macro avg & 0.99 & 0.99 & 0.99 & 10300 \\
\hline weighted avg & 0.99 & 0.99 & 0.99 & 10300 \\
\hline
\end{tabular}

Gambar 10. Report Klasifikasi 


\section{KESIMPULAN}

Kesimpulan yang didapatkan dari eksperimen menggunakan arsitektur Resnet-152 yaitu;

a. Hasil dari eksperimen untuk memprediksi jenis penyakit covid dan pneumonia lainnya dari data image Chest X-Ray menggunakan metode CNN dan arsitektur Resnet-152 adalah sangat baik. Diperoleh hasil dengan nilai presisi tiap kelas lebih dari 95\% yaitu: Covid (99\%), Lung_Opacity (99\%), Normal (98\%), Viral_Pneumonia (98\%). Untuk nilai akurasi secara keseluruhan adalah 99\%.

b. Pemanfaatan AI dalam dunia medis sangat penting, karena dapat membantu pengambilan keputusan kinerja para medis. Terutama untuk diagnosa Covid-19 dapat dilaksanakan dengan cepat, tepat dan biaya yang sangat terjangkau.

c. Untuk pengambilan data image pasien dapat dilakukan dengan cepat dengan menggunakan peralatan rontgen image chest $\mathrm{x}$-ray yang hampir tersedia di seluruh rumah sakit di Indonesia.

d. Hasil model dari penelitian ini dapat digunakan (embeding) dalam bentuk mobile internet atau dalam bentuk sistem yang berbasis web. Sehingga setiap saat dan di manapun berada pasien dapat melakukan scanning dan memperoleh hasil prediksi langsung (real time) dengan cepat.

\section{DAFTAR PUSTAKA}

[1] Ourworldindata.org, "Total Confirmed Deaths," 2021.

[2] W. Hastomo, A. S. Bayangkari Karno, N. Kalbuana, A. Meiriki, and Sutarno, "Characteristic Parameters of Epoch Deep Learning to Predict Covid-19 Data in Indonesia," J. Phys. Conf. Ser., vol. 1933, no. 1, p. 012050, 2021.

[3] H. Mukherjee, S. Ghosh, A. Dhar, S. M. Obaidullah, K. C. Santosh, and K. Roy, "Deep neural network to detect COVID-19: one architecture for both CT Scans and Chest X-rays," Appl. Intell., vol. 51, no. 5, pp. 2777-2789, 2021.

[4] C. J. Huang and P. H. Kuo, "Multiple-Input Deep Convolutional Neural Network Model for Short-Term Photovoltaic Power Forecasting," IEEE Access, vol. 7, pp. 74822-74834, 2019.

[5] L. Wang, Z. Q. Lin, and A. Wong, "COVID-Net: a tailored deep convolutional neural network design for detection of COVID-19 cases from chest X-ray images," 2020.

[6] W. M. Shaban, A. H. Rabie, A. I. Saleh, and M. A. Abo-elsoud, "Detecting COVID-19 patients based on fuzzy inference engine and Deep Neural Network," no. January, 2020.

[7] S. Namasudra, S. Dhamodharavadhani, and R. Rathipriya, "Nonlinear Neural Network Based Forecasting Model for Predicting COVID-19 Cases," Neural Process. Lett., no. 0123456789 , 2021.

[8] R. G. Babukarthik, V. Ananth Krishna Adiga, G. Sambasivam, D. Chandramohan, and A. J. Amudhavel, "Prediction of covid-19 using genetic deep learning convolutional neural network (GDCNN)," IEEE Access, vol. 8, pp. 177647-177666, 2020.

[9] W. Hastomo, "Gesture Recognition For Pencak Silat Tapak Suci Real-Time Animation," vol. 2, pp. 91-102, 2020.

[10] W. Karno, A. S. B., \& Hastomo, "Optimalisasi Data Terbatas Prediksi Jangka Panjang Covid19 Dengan Kombinasi Lstm Dan GRU," Pros. SeNTIK, vol. 4, no. September, pp. 181-191, 2020.

[11] A. S. B. Karno, W. Hastomo, and I. S. K. Wardhana, "Prediksi Jangka Panjang Covid-19 Indonesia Menggunakan Deep Learning Long-Term," Semin. Nas. Teknol. Inf. dan Komun., pp. 483-490, 2020.

[12] P. Lei et al., "Clinical and computed tomographic (CT) images characteristics in the patients with COVID-19 infection: What should radiologists need to know?," J. Xray. Sci. Technol., vol. 28, no. 3, pp. 369-381, 2020. 
[13] J. Zhang, Y. Xie, Y. Li, C. Shen, and Y. Xia, "COVID-19 Screening on Chest X-ray Images Using Deep Learning based Anomaly Detection," arXiv, 2020.

[14] N. Ali, K. Ceren, and P. Ziynet, "Automatic Detection of Coronavirus Disease (COVID-19) Using X-ray Images and Deep.pdf," Pattern Anal. Appl., 2020.

[15] W. C. Dai et al., "CT Imaging and Differential Diagnosis of COVID-19," Can. Assoc. Radiol. $J$, vol. 71, no. 2, pp. 195-200, 2020.

[16] K. He, X. Zhang, S. Ren, and J. Sun, "Deep residual learning for image recognition," Proc. IEEE Comput. Soc. Conf. Comput. Vis. Pattern Recognit., vol. 2016-Decem, pp. 770-778, 2016.

[17] R. Girshick, "Fast R-CNN," Proc. IEEE Int. Conf. Comput. Vis., vol. 2015 Inter, pp. 1440$1448,2015$.

[18] L. M. Rasdi Rere, M. I. Fanany, and A. M. Arymurthy, "Metaheuristic Algorithms for Convolution Neural Network," Comput. Intell. Neurosci., vol. 2016, 2016.

[19] V. Ayumi, L. M. R. Rere, M. I. Fanany, and A. M. Arymurthy, "Optimization of convolutional neural network using microcanonical annealing algorithm," 2016 Int. Conf. Adv. Comput. Sci. Inf. Syst. ICACSIS 2016, pp. 506-511, 2017.

[20] L. M. R. Rere, M. I. Fanany, and A. M. Arymurthy, "Simulated Annealing Algorithm for Deep Learning," Procedia Comput. Sci., vol. 72, pp. 137-144, 2015.

[21] P. Doll, R. Girshick, and F. Ai, "Mask R-CNN ar."

[22] A. G. Howard et al., "MobileNets: Efficient Convolutional Neural Networks for Mobile Vision Applications," 2017.

[23] Corrochann, "COVID-19 Chest X-ray images," kaggle.com, 2020. [Online]. Available: https://www.kaggle.com/datasets?search=chest-xray+.

[24] M. Sandler, A. Howard, M. Zhu, A. Zhmoginov, and L. C. Chen, "MobileNetV2: Inverted Residuals and Linear Bottlenecks," Proc. IEEE Comput. Soc. Conf. Comput. Vis. Pattern Recognit., pp. 4510-4520, 2018. 